\title{
„Wszystko zaczyna się od słów [...]” Filip David i Mirko Kovač: listy o wojnie w byłej Jugosławii
}

\author{
"Everything Begins with Words [...]" \\ Filip David and Mirko Kovač: \\ Letters on War in Former Yugoslavia
}

\begin{abstract}
Aвstract: In the essay the author analyses the problematics of genocide based on correspondence between Filip David and Mirko Kovač Kiedy kwitnie zło. Książka listów 1992-1995 (When evil flourishes. A book of letters 1992-1995) to later juxtapose it with studies on Shoah. She ponders the generational perspective of people whose lives were tarnished by the Nazi-Germany occupation (Filip David - born 1940, Mirko Kovač - born 1938). The article most of all aims at reconstructing the stances of the two authors of letters and showing genocide as a realm of incessant discussion, vague affects, unsystematized knowledge. The author undertakes an attempt to reconstruct only some of the topics and contexts accompanying the issues discussed in David's and Kovač's letters, particularly: the soul-searing descriptions of the Bosnian War of 1992-1995. She shows that the language facet of violence proves to be a challenge to reflecting on literature in the correspondence between the two intellectuals. When faced with the disintegration of hitherto social order in the former Yugoslavia, the nationalist discourse, as social studies and research on genocide suggest, prepares the ground for activation of violent behaviours, justifies them, and plays a key role in fomenting the genocidal repression. As a result of the said processes, the authorities create and reinforce nations' cultural self-images, tighten the control over ethnic purity of collective identity, instigate conflicts between neighbours based on "the blood and soil myth," cherry-pick the xenophobic discourse of the past, and force through with ethnical interpretations of culture.
\end{abstract}

KEY WORDS: Shoah, genocide, ethnic cleansing, Serbia, Croatia

W artykule zamierzam omówić problematykę ludobójczą opisaną w korespondencji Filipa Davida i Mirko Kovača, a następnie zestawić ją z badaniami 
pamięci i Zagłady. Celem tej prezentacji jest rekonstrukcja stanowisk korespondentów i ukazanie ludobójstwa jako obszaru nieustannych dyskusji, niejasnych afektów, nieusystematyzowanej wiedzy.

W obliczu rozpadu socjalistycznej Jugosławii, w atmosferze narastającej wrogości etnicznej, w poczuciu historycznych krzywd wpisanych w sąsiedztwo narodów zachodzą procesy ludobójczej mobilizacji1. Oznacza to, że rozbudzone konfliktem nastroje społeczne, poddawane dyskursywno-instytucjonalnym praktykom władzy, mogą ujawnić groźne, niszczycielskie oblicze. Opowiedziana na dwa, dopełniające się, głosy historia wojny w byłej Jugosławii jest interesująca z wielu powodów. Nie tylko dlatego, że wiele komunikuje na temat czasu historycznego. Autorzy listów współtworzyli środowisko intelektualistów zaangażowanych $\mathrm{w}$ działalność opozycyjną skierowaną przeciwko ugrupowaniom popierającym serbskiego przywódcę politycznego Slobodana Miloševicia. Obaj pisarze wyczuleni byli także na budzące niepokój przejawy narastającego kryzysu. Ich komentarze, zamieszczone w listach, stanowią reakcje tyleż na procesy tu wspomniane, co na możliwe, zgubne ich konsekwencje.

W następstwie prześladowań politycznych Filip David został wyrzucony w 1991 roku z belgradzkiej telewizji z powodu założenia Niezależnego Związku Zawodowego Pracowników Radia i Telewizji. Mirko Kovač, poddany znacznie surowszym represjom policyjnym, ratował się emigracją do Chorwacji. $\mathrm{Na}$ wygnaniu okrzyknięty został „zdrajcą” narodu serbskiego, a w konsekwencji zamieszkał w miasteczku Rovinj na Istrii. Żywiołem autorów listów były publicystyka, polemiki polityczne, ostry sprzeciw wobec propagandy rządu i Kościoła prawosławnego.

Filip David, który wielokrotnie na łamach prasy wypowiadał się na temat dominującego w Serbii w ciągu ostatnich lat „modelu kulturowego”, czy wreszcie Mirko Kovač (prywatna korespondencja pomiędzy Davidem a ostatnim z wymienionych twórców opublikowana jako Knjiga pisama 1992-1995) ostro krytykujący nacjonalizm (nie tylko serbski), należeli w tym czasie, argumentują historycy literatury, do zdecydowanej mniejszości².

Warto dodać jeszcze jeden komentarz, który naświetli złożoną pozycję komentatorów zdarzeń:

Ich postawa, jak się wydaje, była jednak zjawiskiem odosobnionym na tle innych przedstawicieli tej generacji, która nie wypowiadając się na temat reżimu

${ }^{1}$ Zob. L.M. Nijakowski: Rola dyskursu ideologicznego w mobilizacji ludobójczej w XX wieku. „Studia Socjologiczne” 2012, nr 1.

2 S. Nowak-Balcar: Pisarze wobec nacjonalizmu. Dyskusje wobec postaw aktorów społecznych współczesnej serbskiej sceny literackiej. W: Kultury słowiańskie między postkomunizmem a postmodernizmem 1989-2004. Red. M. DąBRowsKa-Partyka. Kraków 2009, s. 149. 
Miloševicia (co odczytywane jest jako milczące pozwolenie), [...] znajdowała się na planie literatury „dysydenckiej”3.

Korespondencja Filipa Davida i Mirko Kovača, opatrzona podtytułem Książka listów 1992-19954, ma politematyczny charakter, niemniej ocena opisywanych zdarzeń nosi znamiona surowego sądu o świecie wojny pełnym przemocy oraz zła.

Warto w tym miejscu postawić pytanie o to, dlaczego tak trudno zrozumieć bałkańskie realia kulturowe ${ }^{5}$. Niestety, każda próba znalezienia odpowiedniego języka dla opisu temperatury etnicznych zatargów powoduje natychmiastowe uwikłanie w dwuznaczne praktyki identyfikowania przyczyn i skutków oraz przywołuje wspomnienie starych konfliktów, które powracają w nowych politycznych układach ${ }^{6}$. Jak pisze Arkadiusz Morawiec:

W przypadku zbrodni popełnionych przez nazistów zarówno zbiór faktów, jak i sfera ocen moralnych są przejrzyste [...]. W przypadku serii wojen związanych z rozpadem Jugosławii wiele kwestii i ocen wciąż pozostaje nieoczywistych?

Chociaż ściszony głos intelektualistów nie może się przebić przez propagandowy „beton”, korespondencję, przy wszystkich jej ograniczeniach ${ }^{8}$, uznać można za formę interesującego komentarza na temat ludobójstwa na Bałkanach i jego kontekstowych uwarunkowań, wreszcie za rodzaj refleksji dotyczącej sytuacji kultury w świecie gwałtownego rozpadu.

Zagłada Żydów stanowi w tym szkicu zaledwie kontekst rozmów o czystkach w byłej Jugosławii, ale kontekst bardzo istotny, wręcz paradygmatyczny, związany z biografią i historią rodziny Filipa Davida. Wątek ocalenia w czasie

3 Tamże.

4 F. David, M. Kovač: Kiedy kwitnie zło. Książka listów 1992-1995. Przeł. G. ŁatuszyńsKi, M. Siwkowska-ŁATuszyńsKa. Warszawa 2001, s. 8.

5 Okoliczności społeczne, polityczne i kulturowe wojny w Serbii interesująco skomentował Pan Miloš Mijatović (doktorant Wydziału Humanistycznego Uniwersytetu Śląskiego). Bardzo dziękuję za rozmowę, w której świadek wojny w byłej Jugosławii zechciał podzielić się ze mną refleksją wspomnieniową, krytyczną i naukową.

${ }^{6}$ Są inne komplikacje - debata publiczna wokół zbrodni ludobójstwa, jak pisze Philip G. Zimbardo, wciąż budzi silne emocje i nie sposób wypracować wspólnych standardów dialogu. Por. Tenże: Słowo wstępne. Przeł. A. Borzecka. W: Krwawy cień genocydu. Pamięć - dyskurs - edukacja. Interdyscyplinarne studia nad ludobójstwem. Cz. 1. Red. B. MACHul-Telus, U. MARKowska-Manista, L.M. Nijakowski. Kraków 2011, s. 11-17.

7 A. Morawiec: Epilog. To się powtarza na naszych oczach - Srebrenica. W: TenżE: Literatura polska wobec ludobójstwa. Rekonesans. Łódź 2018, s. 316.

8 Por. E. RyвіскA: Antropologiczne i komunikacyjne aspekty dyskursu epistolograficznego. W: Narracja i tożsamość. Cz. 1: Narracje w kulturze. Red. W. Bolecki, R. Nycz. Warszawa 2004, s. 206 . 
wojny powraca kilkakrotnie w korespondencji z początku lat 90. W informacji zamieszczonej w liście z 2 czerwca 1992 roku można przeczytać, że w latach 40. ubiegłego wieku pisarz stracił część rodziny w obozach koncentracyjnych na terenie Serbii - w Sajmitšu, w nieznanych grobach chorwackiego Jasenovaca, „bałkańskiego Auschwitz”, w Djakovie, w Kragujevacu. David, czytamy w listach, ocalał pod fałszywym nazwiskiem, przeżył wojnę pod opieką matki we wsi Mandjelos w Banacie. Migawkowe wspomnienia ojca autora, sędziego w Sremskiej Mitrovicy, prześladowanego w trakcie akcji Judenjagd w Belgradzie i ratującego się ostatecznie ucieczką z rodziną na prowincję, nabierają szczególnego znaczenia w komentarzu do współczesnej sytuacji miasta pogrążającego się w chaosie konfliktu wojennego w latach 90. Zagłada Żydów, choć przywoływana zaledwie w kilku wspomnieniowych epizodach życia rodzinnego, jest powracającym w różnych odsłonach ostrzeżeniem przed eskalacją tego, „co kiedyś się wydarzyło", rasizmu, nienawiści, głupoty ${ }^{9}$ Narastanie nastrojów szowinistycznych w Serbii na początku lat 90., zamknięcie w mieszkaniu w Belgradzie pod ostrzałem snajperów - nie tylko spajają plany biografii traumatycznego dzieciństwa Davida i sytuacji aktualnej, ale nadają tym spostrzeżeniom status doświadczenia skłaniającego do podejmowania analizy wojennych zdarzeń. Skłonność do retrospekcji, refleksja, która swym przedmiotem ustanawia obrazy przeszłości, jest cechą charakterystyczną wieku dojrzałego, poszukującego klucza do zrozumienia kryzysu w wojennym Belgradzie. Wypada dodać, że list w monografiach gatunku, sytuowany na granicy sztuki i życia, tworzy pole obserwacji nieuporządkowanych, jednocześnie domagających się namysłu i interpretacji, co dla piszących o wojnie stanowi nie lada wyzwanie ${ }^{10}$. Zmiana rejestrów, tonów, nastrojów w opisach zdarzeń wyposaża „fakty” w wartościujące emocje, które oddalają rozmowę w listach od obiektywnego, literalnego informowania o codzienności. Chaos wojny nie sprzyja także zachowaniu ciągłości wymiany korespondencji. Obserwujemy proces dystrofii zapisów, co przekłada się na objętość poszczególnych rozdziałów datowanych od 1992 roku. Pierwszy zawiera ponad dwadzieścia listów, zbiera fragmenty wykładów i wystąpień publicystycznych Filipa Davida. Ostatni rozdział gromadzi tylko jedenaście zapisów z 1995 roku. Brakuje komentarzy z lipca, dotyczących między innymi masakry w Srebrenicy. Oczywiście powody mogły być prozaiczne - źle funkcjonująca poczta w kryzysowym czasie wojny, o której na marginesie rozmowy wspominają interlokutorzy, wskazując na takie zjawiska, jak: długotrwałe błądzenie listów, przetrzymywanie korespondencji, być może brak informacji o szokujących aktach zbrodni.

${ }^{9}$ Przykładem literatury świadectwa Zagłady, która znalazła swój rezonans na obszarze niemieckojęzycznym, byłaby twórczość serbskiego pisarza pochodzenia żydowskiego Ivana Ivanji, więźnia obozu w Buchenwaldzie, tłumacza literatury serbskiej na język niemiecki.

${ }^{10}$ Por. S. Skwarczyńska: O autonomiczność listu jako rodzaju literackiego. W: TAż: Teoria listu. Oprac. E. Felisiak, M. Leś. Białystok 2006, s. 51. 
Wojna ingeruje w korespondencję pisarzy na różne sposoby, gwałtownie wdziera się wspomnieniami obrazów drastycznych zdarzeń: „snajperzy strzelają do wszystkiego, co się rusza"11, „dzieci okaleczone kulami snajperów błąkają się po spustoszonym kraju”"12, "na belgradzkich ulicach leżą mali żebracy [...], ludzie przechodzą, nikt się nawet nie obejrzy”"13, „popi fotografują się z bronią $\mathrm{w}$ ręku [...], błogosławią kryminalistów złoczyńców $\mathrm{z}$ organizacji paramilitarnych"14, „słuszne jest zabijanie dzieci nieprzyjaciół nawet w kolebce, gdyż te dzieci, kiedy dorosną, będą żołnierzami wrogiej armii”"15, „samobójstw emerytów jest więcej niż kiedykolwiek"16, do nieszczęśliwych rodziców trafiają „zawiadomienia o śmierci dzieci, które zmobilizowano na siłę"17, „czy są straszniejsze czasy, od tych, w których ludzkie głowy zastępują piłkę futbolową?"18, "prowokatorzy policyjni zainicjowali demolowanie i plądrowanie sklepów, a policyjni agenci z telewizji gorliwie fotografowali takie ekscesy"19. Piszących prześladuje dręczące przekonanie, że wszyscy tkwią w ślepej uliczce, nie można bowiem zatrzymać eskalacji przemocy. Opisywane w korespondencji incydenty wojenne, egzystencjalne przeświadczenie, że zło spowszedniało, znalazły interpretacyjną wykładnię w tytule polskiego tłumaczenia książki ${ }^{20}$.

\section{Wszystko zaczyna się od słów}

Z przybierających traumatyczny charakter codziennych doświadczeń wyłania się obraz propagandy, która w refleksji Davida i Kovača traktowana jest przede wszystkim jako dyskurs odpowiedzialny za pogłębianie różnic etnicznych,

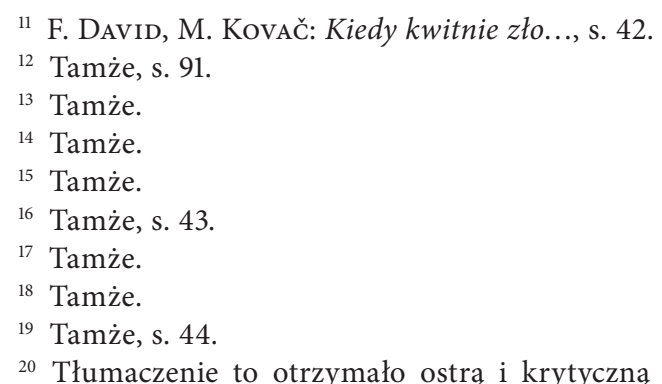
w interpunkcji, błędy gramatyczne. Oryginalny tytuł, przekonuje badaczka, to Książka listów 1992-1995. Jednocześnie autorka recenzji wyeksponowała format intelektualny korespondencji, jej walor jako świadectwa epoki i przykład sztuki epistolarnej. Zob. M. DĄBRowsкA-PARTYKA: Babciuuu! Babciuuu! czyli Dirkem i Doktor ciagną na Lemberg. "Literatura na Świecie” 2003, nr 5-6, s. 395-405. Zob. TAż: Poleżeć na liściach laurowych, albo czego nie wolno tłumaczowi. W: TAż: Świadectwa i mistyfikacje. Przed i po Jugosławii. Kraków 2003, s. 309-324. 
narastanie wzajemnej wrogości sąsiadów, gotowych do wyrównania rachunków krzywd przeszłości ${ }^{21}$. Doznawanie konfliktów, nienawiści, „zwaśnionych pamięci”, towarzyszące opisywanym przez Davida zmianom, buduje silną emocję polityczną. Przeraża rytualizacja permanentnie podgrzewanej przez media atmosfery zagrożeń ze strony Obcego, hierarchiczna struktura "nazi-szaleństwa” powinna bowiem wchłaniać tych, którzy na to zasługują, i wykluczać tych, których nie powinno się przyjmować2 ${ }^{2}$. W komentarzu Davida powracają afekty zdeponowane „w fetyszu Żyda, figurze złowrogiej inności”23. Uwagi te warto umieścić w kontekście przywołanego w liście ze stycznia 1993 roku incydentu: „Wczoraj znów zebraliśmy się przed telewizją i próbowaliśmy wejść na siłę [...]. Nasi niedawni koledzy obojętnie na to patrzyli [...]. Słyszałem, jak jeden $\mathrm{z}$ nich powiedział, widocznie mając na uwadze mój udział $\mathrm{w}$ tym incydencie, że wszystko to jest "żydowska robota «"24. Pisarz zostaje obrzucony „raniącym przezwiskiem" 25 . Kampania medialna ma moc podtrzymywania i mobilizowania nacjonalizmu serbskiego, traktowanego jako jedyny "prawdziwy” patriotyzm, który tak profiluje przestrzeń symboliczną, że zastrzega sobie wyłączność na "prawdę". Myślenie spiskowe, silne w nazistowskiej propagandzie antyżydowskiej, reprodukowane w reżimowym przekazie, wzmaga lęk przed wrogiem, który niszczy Serbię od środka i działa w ukryciu ${ }^{26}$. W kilku autokomentarzach David będzie szukał miejsca dla własnej niestabilnej tożsamości Serba pochodzenia żydowskiego: „Swoje imię i nazwisko, które nie jest "typowo serbskie«, nosiłem bez żadnego wstydu, nigdy mi się nie wydawało dziwne. Dopiero od niedawna wymawiam je z jakimś zahamowaniem"27.

Reżim serbski tworzy alians różnych ideologii: nacjonalistycznych, komunistycznych, faszystowskich - podkreślają publicyści. Tymczasem na każdym z konceptów politycznych zbudowano spójny projekt ludobójczej wyobraźni, który miał przypominać, że tylko niestrudzony, potężny wysiłek propagandy może podtrzymywać i pobudzać gotowość do siłowych rozwiązań sytuacji konfliktowych. By zilustrować tego rodzaju wczesne symptomy zmiany, intelektualiści próbują pokazać, że dyskurs władzy dostarcza mocnego uzasadnienia dla przemocowych zachowań społecznych. Rządzący „spuścili z łańcuchów swoich rasistów i mafiosów, dali im mikrofony i skierowali na nich

${ }^{21}$ Zob. L.M. Nijakowski: Rola dyskursu..., s. 193.

${ }^{22}$ Por. W. Kozio£: Wspólnoty emocjonalne na przykładzie filmu Żmijewskiego „Oni”. Nieudana próba wzmocnienia tożsamości w celu jej rozbrojenia. W: Migracyjna pamięć, wspólnota, tożsamość. Red. R. Sendyka, R. Nycz, T. SAPota. Warszawa 2016, s. 290.

${ }^{23}$ Tamże, s. 287; M. Zaleski: Natręctwo niepamięci naszej o Zagładzie. „Teksty Drugie” 2016, nr 6, s. 101.

${ }^{24}$ F. David, M. Kovač: Kiedy kwitnie zło..., s. 123.

25 J. Butler: Ramy wojny. Kiedy życie godne jest opłakiwania? Przeł. A. Czarnacka. Warszawa 2011, s. 84.

${ }^{26}$ Zob. L.M. Nijakowsкi: Rola dyskursu..., s. 193.

${ }^{27}$ F. David, M. Kovač: Kiedy kwitnie zło..., s. 123. 
kamery”28. Kakofonia komunikatów propagandowych, „wojownicza retoryka i ogłuszający wrzask" 29 medialnych prowokacji tworzą atmosferę narastającej wrogości etnicznej. Dyskusje dotyczące interpretacji przeszłości stanowią jeden z najbardziej żywotnych sporów kulturowych w Serbii i Chorwacji, przenikają także do prywatnej rozmowy w korespondencji ${ }^{30}$. Diagnoza, jaką David stawia w autokomentarzach poświęconych kulturze serbskiej, jest gorzka. Teraźniejsze otwiera się na przeszłość, na stare matryce polityczne, kulturowe i religijne, co prowadzi w ostateczności do zniekształcenia obrazu społeczności:

Na starej matrycy zbudowano nową: internacjonalizm czasów Tity zamieniono na nacjonalizm i religijną podległość komunizmowi, na akceptację i gloryfikację prawosławia jako nowej ideologii, pozostały jednak te same stereotypy i uprzedzenia (oparcie życia publicznego na nieustannym poczuciu zagrożenia ze strony wroga wewnętrznego i konieczności walki przeciwko nie$\mathrm{mu}$ ), przekonanie o istnieniu spisku światowego, czy też mit nierozerwalnej więzi mas ze swoim charyzmatycznym wodzem ${ }^{31}$.

Zauważmy, że komentowany w wypowiedzi Filipa Davida model kultury i przyjęty dyskurs władzy oparty na stereotypach językowych, mitach narodowych stają się ważnym kontekstem analizy zjawiska mobilizacji ludobójczej w Serbii. Wiemy, że chaotyczna nieprzejrzystość wojennych zdarzeń pozwala na upowszechnianie informacji o zagrożeniu, na które należy odpowiadać podwyższoną gotowością do działania. Żyzny grunt dla narastania przemocy stanowi także galopująca inflacja.

W latach dziewięćdziesiątych pogłębia się ekonomiczny regres Belgradu, który przekłada się na sytuacje codzienne: „[...] w ciągu dnia [...] ceny towarów zmieniają się po dwadzieścia razy, [...] pasta do zębów od rana do wieczora podrożała z trzech do stu milionów! Słowa i pojęcia [...] zdewaluowały się tak samo"'32.

28 Tamże, s. 64.

29 Tamże, s. 292.

${ }^{30}$ W latach 1993-1994 utworzono dwa doraźne trybunały do ścigania zbrodni przeciwko ludzkości popełnionych w byłej Jugosławii oraz w Rwandzie. Doprowadziło to do powstania Międzynarodowego Trybunału Karnego z siedzibą w Hadze. Do dziś spływają dowody i świadectwa dramatycznych zdarzeń. Wiemy jednak, że „masowych mordów dopuszczali się nie tylko żołnierze [wszystkich stron konfliktu - G.M.], ale również cywile i grupy paramilitarne. Wszystkie strony tworzyły także obozy, w których przetrzymywano wrogów i dopuszczano się wobec nich bestialstwa [...]. Nie można pominąć w tym miejscu innych przyczyn, które wpłynęły na eskalację konfliktu, jak błędy popełnione przez mocarstwa i organizacje międzynarodowe" (M. ICKIEWICZ-SAWICKa: Prawne i kryminologiczne aspekty zbrodni ludobójstwa serbskiej ludności na Batkanach w XX wieku - wybrane zagadnienia. „ELPIS” 2013, z. 27, s. 174-175).

${ }^{31}$ F. DAvid: Novi-stari kulturalni model. „LiMESplus geopolitički časopis” 2006, nr 2-3, s. 213-214.

32 F. David, M. Kovač: Kiedy kwitnie zło..., s. 164. 
Pensja po wymianie waluty na marki, jeśli tylko była taka możliwość, nie wystarczała na kupno bułki. Zdewaluowana wartość pieniądza szła w parze ze zdewaluowaną wartością języka. Korespondenci pytają, jak radzić sobie z gwałtownym przyrostem politycznego bełkotu, który odbiera znaczenie słowom. Konstatacja o zużywaniu się mowy powraca w innym fragmencie: „Zużyliśmy słowa, słowa są wyświechtane, stare i zmęczone, pozbawione siły [...] naprawienia czegokolwiek, skutecznego przeciwstawienia się jawnym, masowym zbrodniom i zbrodniarzom" ${ }^{33}$. Nieufność do języka wiąże się z historią propagandy, nawarstwiającego się latami kłamstwa ${ }^{34}$, ponieważ wiele konwencji retorycznych z tamtego okresu obowiązywało wciąż w komunikacji politycznej ${ }^{35}$.

W kontekście tych ustaleń wypada przypomnieć, że analiza „nowo-starych” schematów nowomowy była przedmiotem publicystycznych wystąpień Filipa Davida na łamach pism kulturalno-literackich. Szczególny rys działań propagandy, podkreślał pisarz, wiąże się z jej skutecznością kształtującą postawy społeczne za pomocą sprawdzonych, „już istniejących prawd o świecie”, które nazwać można „chorobą przeszłości” ${ }^{36}$. Przez retorykę propagandy przebija ściszony ton prywatnych komentarzy, informujących o upokorzeniach, które towarzyszyły życiu artystów poddanych opresjom mowy nienawiści ${ }^{37}$. Mirko Kovač, nękany w Serbii i Chorwacji anonimami, staje się ofiarą „czystki tożsamościowej”38. Apatryda bez dokumentów i mieszkania nie może przedłużyć ważności paszportu i traci prawo powrotu do Belgradu ${ }^{39}$. Wyemancypowany przemocą, cudzy głos anonimowych gróźb („wyrżniemy ci dzieci” ${ }^{\prime 40}$ ) prześladuje, nęka, odsyła do rzeczywistości, która przenika do listów w krótkich powiadomieniach o lęku o los najbliższych.

33 Tamże, s. 64.

34 Zob. D. GiL: Serbska kultura XXI wieku w karnawałowym zwierciadle „świata na opak”. W: Kultury słowiańskie...

35 Szerzej na ten temat: M. Czerwiński: Nowomowa po jugosłowiańsku. „Studia z Filologii Polskiej i Słowiańskiej” 2012, nr 47, s. 137-159.

36 F. David, M. Kovač: Kiedy kwitnie zło..., s. 211.

37 Por. M. Zaleski: Natręctwo niepamięci naszej o Zagładzie..., s. 95.

38 M. ICKIEWICZ-SAWICKA: Ludobójstwo, czystka etniczna, masakra, pogrom - niedookreślone kategorie zła na przykładzie wybranych konfliktów na Bałkanach. Dostępne w Internecie: https:// repozytorium.uwb.edu.pljspui.bitstream.M_Ickiewicz_Sawicka_[data dostępu: 02.09.2019].

39 Można przywołać w tym miejscu epizod biografii Andreasa Bana, intelektualisty, bohatera powieści Belladonna Dašy Drndić, zmuszonego do opuszczenia Belgradu z powodu serbskiej ksenofobii i panującego tam nacjonalizmu. Zob. S. Giergiel: Andreasa Bana ucieczka ze świata. („Belladonna” Dašy Drndić i „O starzeniu się” Jeana Améry’ego). „Slavica Wratislaviensia” 2016, nr 163, s. 785.

${ }^{40}$ F. David, M. Kovač: Kiedy kwitnie zło..., s. 60. 


\section{Ante bellum ${ }^{41}$}

Można się chyba zgodzić, że analizowana w korespondencji humanistów wizja Serbii popadającej w szaleństwo nienawiści wiąże się z kategorią, którą socjologowie określają mianem „dylematu bezpieczeństwa”" (jedna z grup etnicznych traktuje drugą jako przeszkodę do bezpiecznego życia). Łatwo zauważyć, że problem ten dotyczy konfliktogennej kwestii czystości etnicznej narodów bałkańskich, zjawiska dostarczającego, jak pisze amerykański antropolog kultury Arjun Appadurai, wielu argumentów wspierających praktyki ludobójcze w świecie globalizacji XX wieku ${ }^{43}$. Sprawa związana $\mathrm{z}$ dynamiką więzi grupowych, poddawanych manipulacjom medialnym, znajduje interesujące ujęcie $\mathrm{w}$ komentarzu poświęconym zagadnieniu „mobilizacji drapieżczych tożsamości”"4. Appadurai pisze: „Przekształcenie etnosu w nowoczesny naród często stwarza grunt dla pojawienia się drapieżczych tożsamości, tożsamości, które utrzymują, że dla ich przetrwania niezbędna jest zagłada innej zbiorowości" ${ }^{\prime 4}$. Można wnioskować, dodaje badacz, że „tożsamości drapieżcze rozwijają się w luce między poczuciem liczebnej większości a marzeniem o narodowej czystości i pełności, którym mała liczba zagraża" ${ }^{\prime \prime 6}$. Dzieje się tak za sprawą łatwo przenikającej do świadomości społecznej zasady instrumentalizacji różnicy etnicznej, co redukuje widzenie Innego do negatywnego obrazu wroga ${ }^{47}$. Jeśli nie można poradzić sobie z Innym, należy go wykluczyć - być może wtedy wspólnota odzyska swoją etniczną spójność i poczucie bezpieczeństwa. Mechanizmy kontrolowania narodu według zasady czystej tożsamości nasilają się w sytuacjach kryzysu, kiedy społeczności grozi rozpad. Narasta wtedy nienawiść wkraczająca w relacje

41 „Podkreślono, iż w ostatniej dekadzie XX wieku na obszarze jugosłowiańskim doszło do swoistego "powrotu historii«, wyrażającego się w dążeniach narodów bałkańskich do odwrócenia niekorzystnych procesów historycznych [...]. Skomplikowana historia regionu Bałkanów, w tym wielowiekowe panowanie Turcji, nierozwiązane i sięgające mniej lub bardziej odległej przeszłości spory terytorialne, okresy otwartej, zbrojnej konfrontacji, ugruntowane w pamięci zbiorowej negatywne doświadczenie wzajemnych relacji i wspólnej państwowości [...] oraz wieloletnia, dająca o sobie znać polityka zewnętrznego paternalizmu nie stanowiła wprawdzie głównego powodu dezintegracji SFRJ, ale w istotnym stopniu przyczyniła się do [...] wybuchu konfliktów zbrojnych" (K. PAwŁowski: Ante bellum. Uwarunkowania historyczne procesów dezintegracyjnych na terytorium Socjalistycznej Federacyjnej Republiki Jugosławii i jej państw sukcesyjnych po zimnej wojnie. „Annales Universitatis Mariae Curie-Skłodowska. Sectio K. Politologia” 2017, Vol. 24, no 2, s. 47).

42 L.M. Nijakowski: Rola dyskursu..., s. 194.

43 Por. A. Appadurai: Tożsamości drapieżcze. W: Tenże: Strach przed mniejszościami. Esej o geografii gniewu. Przeł. M. Bucholc. Warszawa 2009, s. 57.

44 Tamże.

45 Tamże.

46 Tamże.

47 Por. F. David, M. Kovač: Kiedy kwitnie zło..., s. 145. 
sąsiedzkie i rodzinne. Na obszarze wieloetnicznej Jugosławii, pisze Filip David, zjawisko to przybrało monstrualne rozmiary:

[...] blisko dziesięć milionów mieszkańców byłej Jugosławii jest wymieszanych etnicznie. I ten fakt w każdej racjonalnej analizie byłby dowodem na to, że wojna jest niemożliwa, w rzeczywistości przyczynił się do strasznych podziałów: ojciec ruszył na syna, brat na brata, krewny na krewnego. Wszystko stało się irracjonalne. Zamknęły się krwawe kręgi i doszło do bezlitosnej rzezi. Staliśmy się najgorszym z przykładów samozagłady ${ }^{48}$.

Co gorsza, podpowiada Mirko Kovač, nacje te są sobie potrzebne, ponieważ bez Obcego ich tożsamość własna pozostaje niepewna. „Teraz tak myślę sobie, że te nasze narody, szczególnie Serbowie i Chorwaci, odcinając się od siebie nawzajem, związane są ze sobą jakąś "wewnętrzną symetrią przekleństwa" i że wiele $\mathrm{z}$ tego, co jest między nimi, trudno jest rozdzielić"'t9. Jak podpowiada Apparduai, dynamika relacji etnicznych rządzi się swoimi prawami, współtworzy zmienny i nieokreślony sposób budowania lokalnego ładu, jej konfliktogenna atmosfera wrogości nie ma zatem stałego charakteru. Trzeba ją regularnie „mobilizować i pobudzać potężnymi kampaniami rasistowskimi i politycznymi” "50, dla których, zdaniem badacza, ważnym kontekstem historycznym i punktem odniesienia jest nazistowska propaganda antyżydowska. Można przypisywać Innym odpowiedzialność za zbrodnie zgodnie z założeniami „wojny obronnej” i „sprawiedliwej”, kreującej wizerunek winnego, którym zawsze jest ten drugi:

Mimo tylu popełnionych zbrodni nie ma zbrodniarzy. Nie ma zbrodniarzy, bo my nie uczestniczyliśmy w wojnie! W Chorwacji, (jak sam wspominasz): Myśmy się bronili, a jak ktoś się broni, nie może dokonywać zbrodni! Nie znaczy to, że zrównuję winę, ale winnych jest dużo, tak jak cierpienia jest zbyt wiele. Niebezpiecznie jest żyć w przekonaniu, że zbrodnia jest dokonywana tylko przez tego drugiego. $\mathrm{W}$ zbrodni się człowiek nurza z powodu nienawiści, zemsty, z powodu chęci wyrównywania starych i nowych długów ${ }^{51}$.

Mroczna prawda nie ma swego adresu, trwa poddana afektywnej pamięci. Tożsamość Serbów tworzy się i odnawia przez preferowanie więzi „między swoimi”, przez politykę pamięci i zasadę posłuszeństwa wobec tradycji. Przypominanie ofiar przeszłości w głośnych celebracjach narodowych uroczystości i w ściszonych emocjach ekshumacji umacnia obrzędowy tradycjonalizm: „[... to wykopywanie kości z pieczary w Prebilovcach, a nad pieczarą i kośćmi

\footnotetext{
48 Tamże, s. 152.

49 Tamże, s. 250.

50 A. Appadurai: Tó̇samości drapieżcze..., s. 57.

${ }^{51}$ F. David, M. Kovač: Kiedy kwitnie zło..., s. 293.
} 
same serbskie wielkości" ${ }^{2}$. Nie mniej ważne pozostaje sakralizowanie heroicznej walki, każdy patriota zobowiązany jest bowiem do zabijania w imię obrony narodowego państwa. David pisze w liście z listopada 1993 roku: „[...] pewien chłopak ukrywa się zarówno przed własnym ojcem, jak i przed żandarmerią wojskową. Dla ojca to największy zaszczyt (czego jego syn nie chce zaakceptować) oddać życie dla ojczyzny (nawet takiej, jak nasza)"53. Zapis zwaśnionych pamięci przechowuje poezja. Oto fragment Memoari Nikifora Ninkovicia, golibrody księcia Miloša: „[...] »skłócę wioskę z wioską, sąsiada z sąsiadem, tu mu głowę odsieką, tam go kołem będą łamać, przystroją ludźmi drzewo "" "54. Tematyka przekazów przeszłości i poetyka pieśni są podobne, różnice polegają na odmiennej tożsamości etnicznej protagonisty pozytywnego i negatywnego. Nie ma bohatera, pisze Kovač, jeśli się nie wykaże w bratobójczej wojnie - i przesyła Davidowi, w liście z lutego 1993 roku, wiersz zatytułowany Idylla zimowa: „[...] swój barłóg ścielę / w nim Chorwatki dwie / ja serbski heros z pola walki / zapładniam te lalki / gdy trzeba zabiję / nieważne kogo / niech Serbia żyje"55.

Trzeba tu wspomnieć o negatywnym stereotypie mieszkańca „dzikich Bałkanów”, który „niemal fatalistycznie utknął w pułapce własnej historii”" ${ }^{” 6}$. W aurze oficjalnie proponowanej propagandy, operującej kategorią ciągłego zagrożenia, preferującej wybrane dyskursy przeszłości, bez pogłębiania wątków, które z perspektywy teraźniejszości są niewygodne, brakuje refleksji nad skomplikowaną historią regionu. Żeby wyostrzyć samowiedzę w sytuacji ujawniającej liczne niedomówienia i wątpliwości, Kovač przywołuje w listach wspomnienia rozmów i wywiadów medialnych przeprowadzonych poza granicami Belgradu. Kłopot polega na tym, że konflikty wywoływane przez etniczne podziały są niewytłumaczalne, traktowane jak miejsca problematyczne, wskazujące na brak „konceptu” do regulowania kontyngentnych relacji ${ }^{57}$. Dziennikarze prasy zagranicznej odpowiadają narracją, którą stworzyła hegemoniczna, zachodnia historiografia: „Dziennikarz pyta mnie, dlaczego Serbowie są w konflikcie ze wszystkimi? [...] Skąd to opętanie na punkcie terytorium i przestrzeni życiowej? Czy nie jest dla nich problemem brak perspektywy, izolacja, odszczepieństwo od Europy?"58. W innym miejscu David dopełnia ten obraz konstatacją: „Dziennikarze zagraniczni, »humanitaryści«, dyplomaci - wszyscy przybywają nafaszerowani Dostojewskim, błędnie odczytanym, Njegoszem i Andriciem, przekonani, że wszystko zrozumieli, przedstawiając nam swoje dowody naukowe, właściwie nic nie rozumiejąc" 59 .

\footnotetext{
52 Tamże, s. 149.

53 Tamże, s. 195.

54 Tamże, s. 130.

55 Tamże, s. 141.

56 K. PawŁowski: Ante bellum..., s. 47.

57 Por. tamże.

58 F. David, M. Kovač: Kiedy kwitnie zło..., s. 30-31.

59 Tamże, s. 133.
} 
Kovač w liście z 24 lutego 1992 roku przypomina wywiad z Nicole Zand z „Le Monde”, w którym próbuje wyjaśnić „idee zaścianka”. Indagowany przez dziennikarkę intelektualista odsyła do książki belgradzkiego krytyka i eseisty, diagnosty serbskiego nacjonalizmu. Oto fragment rozmowy: „»Jeśli Pan miałby polecić jakąś książkę do tłumaczenia, co by to było? « pyta Nicole. - Filozofia zaścianka Radomira Konstantinovicia - odpowiadam - jeśliby Francuzi w ogóle mogli i chcieli tę książkę zrozumieć"60. Trudność komunikacji wywołuje efekt obcości. Obraz kultury własnej, związany z pozytywnym odczuciem narodowej dumy, daje podstawy do budowania silnej tożsamości zbiorowej. Kryzys ekonomiczny, gwałtowne osłabienie pozycji politycznej i militarnej Serbii na arenie międzynarodowej w połowie lat 90. nie pozostawiały nadziei na poprawę warunków życia. W tych okolicznościach odczucie dojmującego regresu i politycznej marginalizacji w Europie, o którym niejednokrotnie przypominają autorzy listów, skutkować mogło narastaniem społecznej frustracji, co gorsza, groziło eskalacją narodowych kompleksów, przeradzających się w niebezpieczne odczucie wyższości kulturowej nad innymi narodami. Co zatem wpycha Serbię w peryferyjne oddalenie od Europy? - pytają intelektualiści. W badaniach inspirowanych postkolonialną reinterpretacją historii włączeni jesteśmy (Polska, Ukraina, Serbia, Chorwacja) w pas peryferyjnej Europy Wschodniej i Południowej, w obszar kulturowo osobliwy, rozmyty, niewyraźny, usytuowany między Wschodem i Zachodem, wpisany w opozycje demokracji i totalitaryzmu, rozumu i siły, dzikości i instytucjonalizacji, chociaż zestawienia te mają „czysto fantazmatyczną zawartość: nie opisują żadnego stanu rzeczywistego i odpowiadają jedynie obecnemu po obu stronach pragnieniu określonej percepcji samego siebie oraz innego" 61 .

\section{Zakończenie}

Listy Filipa Davida, Serba żydowskiego pochodzenia, i Mirko Kovača, Chorwata urodzonego w Czarnogórze, w przekładzie polskim zatytułowane Kiedy kwitnie zło. Książka listów 1992-1995, osadzone w atmosferze wydarzeń lat 90. XX wieku w byłej Jugosławii, współtworzą żyjący własnym życiem, intelektualny dwugłos ${ }^{62}$. W szkicu starałam się wyeksponować perspektywę

60 Tamże, s. 28.

${ }^{61}$ J. SowA: Fantomowe ciało króla. Peryferyjne zmagania z nowoczesnością. Kraków 2011, s. 13.

${ }^{62}$ Listy wprowadzają w materię relacji o kryzysie wątki kanonicznych tekstów literatury światowej i rodzimej. Kwestia ta pozostaje poza moimi zainteresowaniami w tym szkicu. Wymieńmy tylko niektóre przykłady nawiązań: Fiodor Dostojewski, Isaac Bashevis Singer, Franz 
generacyjną pokolenia naznaczonego piętnem doświadczeń okupacji hitlerowskiej. Czy autorom listów udało się, oprócz wpisania ludobójstwa w szerokie spektrum rozważań politycznych, społecznych, literackich, dotknąć specyfiki indygenicznych relacji kulturowych oraz wyjść poza sferę publicystycznych rozpoznań ${ }^{63}$ ? Zapytać wypada także, czy dla urodzonych później świadków wojny na Bałkanach Holokaust, wpisany w różne narracje kolektywnej pamięci (idea walki z faszystami w powojennej Jugosławii, ujawniona po rozpadzie Jugosławii niewygodna prawda o kolaboracji Chorwatów z Niemcami), stanowi klucz do zrozumienia mechanizmów przemocy wojny lat $90 .{ }^{64}$ ? W korespondencji Filipa Davida zagłada Żydów i pamięć o pomordowanych tworzą kontekst dla sytuacji ogarniętego wojną Belgradu (śmierć na ulicach, głód, akty ludobójcze). Wyrastająca z fragmentarycznych odpomnień okupacji opowieść pisarza przesiąknięta jest traumatycznym doświadczeniem przeszłości, naznaczona lękiem, że sytuacja zagrożenia może się powtórzyć. Zagłada stanowi przestrogę, przypomina nam, kim stajemy się w obliczu potężnych kryzysów politycznych, militarnych, ekonomicznych. „To, co wydarzyło się wcześniej, może wydarzyć się ponownie”65. Zauważmy, że obserwacja zdarzeń w objętymi wojną Serbii i Chorwacji uświadamia zaangażowanym uczestnikom życia publicznego, że w obliczu rozpadu dotychczasowego ładu społecznego na Bałkanach nacjonalistyczny dyskurs, jak podpowiadają badania socjologiczne i studia nad genocydem, skutecznie

Kafka, Thomas Mann. Przypomnijmy też wybrane nazwiska największych pisarzy pokolenia, mentorów wyznaczających rudymenty moralne dla generacji powojennej w Serbii: noblista Ivo Andrić - „pisarz pogranicza”, Danilo Kiš - „pisarz Zagłady”, Borislav Pekić, podejmujący zagadnienia postaw moralnych w świecie okupacji hitlerowskiej. Także polscy pisarze i poeci: Czesław Miłosz, Wisława Szymborska, Witold Gombrowicz.

${ }^{63}$ Listy czytać można w kontekście etycznym, liczne komentarze piszących stanowią rodzaj apelu do czytelnika, by ten nie pozostawał bierny. W tym miejscu dla porównania warto przywołać kontekst prozy Dašy Drndić. Pamięć Zagłady uobecnia się w utworach chorwackiej pisarki poprzez składnię wyliczenia, formalne spisy zrabowanego mienia żydowskiego w Zagrzebiu. Linearny tok narracji i komentarza delimitują przywoływane archiwalne listy zamordowanych Żydów, rejestry przedmiotów, fotografii, które mają wartość dokumentu i afektywnego obrazu. W powieści Belladonna, pisze Sabina Giergiel, wewnętrzne okładki książki wyposażone zostały w rodzaj kopert. „W nich czytelnik znajdzie nazwiska żydowskich dzieci z Hagi (2061), zaginionych podczas wojny [...] oraz listę żydowskich ofiar, które przebywały w obozie w Šabcu (Serbia) [...]” (TAż: Wędrując śladami umartych. Foto-teksty Dašy Drndić. „Balcanica Posnaniensia" 2018, nr 25, s. 193).

${ }^{64}$ Pytanie to wymagałoby szczegółowej analizy recepcji literatury najnowszej. Warto zaznaczyć, że Zagłada, pozostająca paradygmatycznym odniesieniem dla generacji, która przeżyła okupację hitlerowską, nie stanowi narracji dominującej w literackich świadectwach młodych pisarzy podejmujących temat wojny w byłej Jugosławii. Doświadczenie klęski, jaką poniosła kultura w zderzeniu z traumą przemocy, świadomość, że ludobójstwo nie ma swojej prawdy językowej, podpowiada twórczość Vladimira Tabaševića, pisarza urodzonego w latach 80., mieszkającego w Belgradzie, laureata licznych nagród literackich.

${ }^{65}$ Y. Bauer: Porównanie z innymi przypadkami ludobójstwa. W: Tenże: Przemyśleć Zagładę. Przeł. J. GiebuŁtowski, J. Surewicz. Warszawa 2016, s. 100. 
przygotowuje grunt dla aktywizacji zachowań przemocowych, usprawiedliwia je i odgrywa kluczową rolę w mobilizacji ludobójczej represji. W rezultacie tych procesów władza tworzy i umacnia obraz kultury własnej narodu, poddaje tożsamość wspólną kontroli czystości etnicznej, konfliktuje sąsiadów wokół „mitu ziemi i krwi”, wybiera ksenofobiczne dyskursy przeszłości, forsuje etniczne interpretacje kultury ${ }^{66}$. Działanie to rodzi emocje polityczne, podsyca resentymenty. Po obu stronach konfliktu są świadkowie poszukujący dyskursu "prawdy” i są pokrzywdzeni ${ }^{67}$.

\section{Bibliografia}

Appadurai A.: Tożsamości drapieżcze. W: A. Appadurai: Strach przed mniejszościami. Esej o geografi gniewu. Przeł. M. Bucholc. Warszawa 2009, s. 50-120.

Bauer Y.: Przemyśleć Zagładę. Przeł. J. GiebuŁtowski, J. Surewicz. Warszawa 2016.

Butler J.: Ramy wojny. Kiedy życie godne jest opłakiwania? Przeł. A. Czarnacka. Warszawa 2011.

Czerwiński M.: Nowomowa po jugosłowiańsku. „Studia z Filologii Polskiej i Słowiańskiej” 2012, nr 47, s. 137-159.

David F., Kovač M.: Kiedy kwitnie zło. Książka listów 1992-1995. Przeł. G. ŁatuszyńSKI, M. SiwkowsKa-ŁatuszyńsKa. Warszawa 2001.

Dąbrowska-Partyka M.: Babciuuu! Babciuuu! czyli Dirkem i Doktor ciagna na Lemberg. „Literatura na Świecie” 2003, nr 5-6, s. 395-405.

DąBrowska-Partyka M.: Poleżeć na liściach laurowych, albo czego nie wolno tłumaczowi. W: M. Dąbrowska-Partyka: Świadectwa i mistyfikacje. Przed i po Jugosławii. Kraków 2003, s. 309-324.

DĄBRowsKa-PARTYKa M.: Zagadnienie tożsamości a konflikt jugosłowiański. W: Wspótcześni Słowianie. Red. M. Bobrownicka, L. Suchanek, F. Ziejka. Kraków 1997, s. 60-67.

Giergiel S.: Andreasa Bana ucieczka ze świata. („Belladonna” Dašy Drndić i „O starzeniu się" Jeana Améry'ego). „Slavica Wratislaviensia” 2016, nr 163, s. 783-793.

Giergiel S.: Wędrując śladami umarlych. Foto-teksty Dašy Drndić. „Balcanica Posnaniensia” 2018, nr 25, s. 181-196.

ICKIEWICZ-SAWICKA M.: Ludobójstwo, czystka etniczna, masakra, pogrom - niedookreślone kategorie zła na przykładzie wybranych konfliktów na Bałkanach. Dostępne

${ }^{66}$ Zob. B. Machul-Telus, U. Markowska-Manista, L.M. Nijakowski: Wprowadzenie. Wiele ludobójstw, jeden dyskurs? W: Krwawy cień genocydu..., s. 18.

${ }^{67}$ Maria DąBRowsKa-Partyka przekonująco wykazuje, że w dyskusjach literackich dotyczących wydarzeń w byłej Jugosławii po 1991 roku kluczowe dla refleksji tożsamościowej było "pytanie o to, kim jestem ja sam i czym jest to »my«, do którego mnie przypisano, z którym się identyfikuję?" (TAż: Zagadnienie tożsamości a konflikt jugosłowiański. W: Współcześni Słowianie. Red. M. Bobrownicka, L. Suchanek, F. Ziejka. Kraków 1997, s. 63). 
w Internecie: https://repozytorium.uwb.edu.pljspui.bitstream.M_Ickiewicz_Sawi cka_ [data dostępu: 02.09.2019].

ICKIEWICZ-SAWICKA M.: Prawne i kryminologiczne aspekty zbrodni ludobójstwa serbskiej ludności na Bałkanach w XX wieku - wybrane zagadnienia. „ELPIS” 2013, z. 27, s. $173-180$.

Kozıoє W.: Wspólnoty emocjonalne na przykładzie filmu Żmijewskiego „Oni”. Nieudana próba wzmocnienia tożsamości w celu jej rozbrojenia. W: Migracyjna pamięć, wspólnota, tożsamość. Red. R. Sendy KA, R. NyCz, T. SA POTA. Warszawa 2016, s. 285-305.

Krwawy cień genocydu. Pamięć - dyskurs - edukacja. Interdyscyplinarne studia nad ludobójstwem. Cz. 1. Red. B. Machul-Telus, U. Markowska-Manista, L.M. NiJAKOWSKI. Kraków 2011.

Kultury słowiańskie między postkomunizmem a postmodernizmem 1989-2004. Red. M. DąBrowska-PARTyka. Kraków 2009.

Morawiec A.: Literatura polska wobec ludobójstwa. Rekonesans. Łódź 2018.

Nijakowski L.M.: Rola dyskursu ideologicznego w mobilizacji ludobójczej w XX wieku. „Studia Socjologiczne” 2012, nr 1, s. 177-198.

PAwŁowsKi K.: Ante bellum. Uwarunkowania historyczne procesów dezintegracyjnych na terytorium Socjalistycznej Federacyjnej Republiki Jugosławii i jej państw sukcesyjnych po zimnej wojnie. „Annales Universitatis Mariae Curie-Skłodowska. Sectio K. Politologia" 2017, Vol. 24, no 2, s. 47-73.

RyвickA E.: Antropologiczne i komunikacyjne aspekty dyskursu epistolograficznego. W: Narracja i tożsamość. Cz. 1: Narracje w kulturze. Red. W. Bolecki, R. Nycz. Warszawa 2004, s. 203-230.

Skwarczyńska S.: Teoria listu. Oprac. E. Felisiak, M. Leś. Białystok 2006.

Sowa J.: Fantomowe ciało króla. Peryferyjne zmagania z nowoczesnością. Kraków 2011.

Zaleski M.: Natręctwo niepamięci naszej o Zagładzie. „Teksty Drugie” 2016, nr 6, s. 95-101.

Grażyna Maroszczuk - dr hab., prof. UŚ, pracownik Wydziału Humanistycznego Uniwersytetu Śląskiego. Historyk literatury, badaczka prozy XX i XXI wieku. W swoich studiach pyta o egzystencjalny wymiar literatury, zapisaną $\mathrm{w}$ prozie specyfikę nowoczesnego doświadczenia, prozatorskie świadectwa trwania wobec przemocy Historii. Opublikowała: Dyskurs i historie. O powieściach Andrzeja Szczypiorskiego (2004) oraz Świadectwa - rozmowy - kreacje. W kręgu tekstów interlokucyjnych (2012), współredaktorka leksykonu Pisma kulturalne w Polsce po 1989 roku (2010) oraz książek Proza polska XX wieku. Przeglądy i interpretacje. T. 3 (2014), Rzeczywistość i zmyślenie. Światy przedstawione $w$ literaturze $i$ kulturze XIX-XXI wieku (2017). Autorka licznych artykułów w pracach zbiorowych i pismach kulturalno-literackich. 